\title{
Micro, Small and Medium Enterprises (MSMEs) under the threat of COVID-19 Pandemic in India: Problems, Challenges and Strategies for Revival
}

\author{
${ }^{1}$ Shila Kumari \\ ${ }^{2}$ Dr. Pushpa Kumari
}

\begin{abstract}
Due to the outbreak of epidemic COVID-19 whole world is facing two-way crisis first as COVID-19 outbreak and economic crisis. It has been drastically impacted the socio -economic, political and psychological conditions of all nations specially developing countries like India. As social distancing is the only precaution to avoid the virus, a nationwide lockdown has been imposed which has influenced almost every aspect of the global economy as well as India. The backbone of Indian Industry, Micro, Small and Medium Enterprises (MSMEs) has been affected badly for the last couple of months due to COVID-19. MSME sector has been facing huge number of problems and challenges due to this world-wide pandemic outbreak. The researcher identified the problems faced by MSMEs during the lockdown like disruptive supply chain, low demand, clean out wasted stocks and shortage of human resource. Paper also discusses the role of government initiatives and analyzed the challenges and issues facing by MSMEs in present economic scenario on the basis of extensive literature review. Outcome of the study will help to strategies formulation to revive the MSMEs to come out from the recent crisis.
\end{abstract}

Key word: MSME, challenges, government initiative, COVID - 19, Aatm Nirbhar Bharat Yojana.

Corresponding Author: ${ }^{1}$ Shila Kumari, Research Scholar, University Department of Economics, BBMK University Dhanbad. Email: shila.himani55@gmail.com

${ }^{2}$ Associate Professor, University Department of Economics BBMK University, Dhanbad.

\section{Introduction}

Micro Small and Medium Enterprises are considered as the backbone of Indian industry. It is the second largest sector in generating employment and been creating 11.10 crore job across the India. According to DGCIS (directorate general of commercial intelligence and statistics) data, the value of product related to MSME sector is $\$ 147,390.08$ million and contributed $48.56 \%$ of total export during $2017-18$ 
[1]. MSME sector has revealed higher level of integration with global value and supply chain. The sector has contributed $29 \%$ of overall GDP in the data 2019 [2].

India has been facing two crises side by side, the pandemic and the economic crises. The COVID-19 not only affected the health and lives of people but it also have been affecting the many sectors of Indian economy. The nation-wide lockdown adopted during COVID-19 has directly impacted the business industry mostly the MSME sector which has large contribution in the Economy. With this extended lockdown each personnel related with MSME sectors affected. During this COVID-19 situation owners, employees and stakeholders related to MSME affected, Regular manufacturing halted due to stopped demand, Enterprises were standing idle, many entrepreneurs has temporarily shut down their businesses during this pandemic situation, many Enterprises laid-off their workers as they were unable to pay their salaries, MSME sector has a large global supply chain which collapsed during this pandemic and a large number of workers migrated as they lost their jobs. Livelihood of a huge population has been affected under the threat of COVID-19.

During this pandemic many revival strategies were introduced and adopted by Government of India for MSMEs to survive. Aatm Nirbhar Bharat Yojana introduced by Govt. of India in mid COVID-19 situation with the package of 20 lakh crore rupee for Indian economy. For the revival and growth of MSME sector 3.7 lakh crore collateral free loan package has introduced under this scheme. The classification of MSME has also been revised in this scheme.

\section{Rational of the Study}

The whole world grapples with COVID-19 pandemic that has shook the world and impacted the regular lives globally. This terrible situation hampered peoples to step out from home. During COVID-19 situation almost every sector of Indian economy was affected and the MSME sector was affected mostly. Almost every nation has adopted lockdown to suppress the effect of COVID-19. This lockdown created many problems for both household and business. Many enterprises shut down their business, workers migrated to their home town or villages, investment and consumption declined, supply chain disrupted which created problem to entrepreneurs to run and expand their businesses. This study aims to highlight the problems and challenges they faced during COVID-18 to find out the possible solution to cater them. This study has also discussed the economic relief provided by government amid COVID-19.

\section{Research Gap}

There has been immense number of research on MSME sector, but not much micro level study has been done in this field. There has not been any study regarding the conditions of MSME during COVID-19 in Jharkhand state. The present study is proposed to study the problems and conditions of MSMEs in Dhanbad, Bokaro and 
Ranchi District. Results are expected to find out post pandemic revival strategies for MSMEs to sustain.

\section{Aims and Objective}

The paper aims to study the problems and challenges faced by entrepreneurs of MSME and the government initiatives taken for the revival of MSMEs. A Case Study has been conducted on some MSMEs of Dhanbad, Bokaro and Ranchi District of Jharkhand State to know how they are managing their business during the pandemic and what kind of problems and challenges they are facing in this COVID19 situation. The study also came up with post pandemic revival practice to overcome in the future.

\section{Literature review}

Prasanna, P. J. (2017) [3] stated in his study that MSME sector provides uniform development to the society and is helpful I removing regional imbalances. it is also mentioned that MSME sector is needed to focus on areas of technology \& environment, market accessibility, industrial bottlenecks, Mentoring and Advocacy and Credit accessibility to strengthen the MSME sector. Ahmed, I. (2017) [4] studied the major challenges faced by entrepreneurs in Jammu \& Kashmir using the secondary source of data in Jammu Kashmir problem of lack of basic knowledge and lack of social and family support is found. Revamped education sector with the emphasis of science and technology, change of mind set of people to embrace selfemployment, innovative ideas with financial support needed in Jammu \& Kashmir for the growth of women entrepreneurs. Kulkarni, D. (2020)[5] mentioned the challenges of transforming the huge unregistered MSME into registered, improving the competitiveness of the overall MSME sector. The study discussed the measure taken by government and RBI to curb the impact of COVID-19 pandemic.

Panda, A. K. (2020) [6] Looked towards the problems \& challenges the sector face due to COVID-19 and thinks the possible way to mitigate the problems in the study-term so that the units survive and stand again and the opportunities possible in Odisha state. It has focused upon the resources, manpower, available in the state. Handloom $\&$ handcraft export focused on capital arrangement facilitated.

Lal, et al. (2020) [7] highlighted the considerable role of MSME on Indian economy and examined some problems faced by the sector like; lack of labour supply, disruption in demand \& supply and lack of credit and liquidity flow. It is also said that MSME sector can be rejuvenated by building economic resilience if government consolation measures enforced effectively.

Sipahi, E. (2020),[8] studied the problem incurred by MSME during Covid 19 and the measure taken for the revival of MSME sector. It is also studied that the measures like; financial aid, opportunities, wage support, utility and social security payments and preparedness for future will not be beneficial for informal sector to pay income 
tax and to be registered under the GST as the employment and turnover will not meet minimum thresholds required.

Affandi, A et al. (2020) [9] studied that MSMEs faced global competition during COVID-19 Pandemic in Indonesia and stated that with government supports and various government policies optimization of the empowerment of MSMEs and making MSMEs able to face the competition in global market in this pandemic will be possible. Using descriptive exploratory approach, the role of government intervention and policies are discussed. It is recommended that with innovation, creativity and other marketing strategies MSMEs will be able to recover in this pandemic.

Sahoo, P., \& Ashwani. (2020)[10] using secondary source of data from various reports and publication of ministries assessed the impact of COVID-19 on the growth, manufacturing, trade and MSMEs of the Indian Economy. It is stated that in 2020 over the previous year manufacturing sector may shrink from 5.5 to $20 \%$, exports and imports may shrink 13.7 to $20.8 \%$ and 17.3 to $25 \%$ respectively and MSME net value added from 2.1 to $5.7 \%$. it is mentioned that hardly $0.5 \%$ growth can be managed by Indian economy.

Dubey \& Sahu (2020) [11] Studied the condition of Micro, Small and Medium Enterprise in COVID-19 Pandemic and Atmanirbhar Bharat the economic relief package with its critical analyses. It is studied that under the pandemic $25 \%$ of MSMEs will shut down if lockdown continues for four week and $43 \%$ if continues for eight weeks. During the pandemic Indian economy is facing economic slowdown caused by decreasing demand and revenue and this slowdown may aggravate further.

Roy et al. (2020) [12] studied the impact of COVID-19 crisis on MSME sector in India and found that 50\% MSME units suffered by 20-25\% losses during the pandemic and during this pandemic manufacturing and retail firms have temporarily shut down their businesses. It is also found that the economic relief package is not sufficient to compensate the losses occurred. It is also highlighted that small businesses may fall in contractions due to negative growth rate of net sales.

Jha \& Kumar, (2020) [13] provided a razor-sharp commentary on the economic relief package announced by government of India and this package is criticized on many grounds. It is highlighted that stakeholders of MSMEs have mixed reactions for the new definition of MSME. Some of the stakeholders were not appreciating the changing classification of MSME. It is also highlighted that during the COVID-19 crisis demand for products and services were low and without increasing the purchasing power parity of the consumers, revival of MSMEs will be challenging and business offerings will not be taken in the market. It is suggested that government can reduce GST to increase the purchasing of consumers. 
Chaudhary et al. (2020) [14] assessed the impact of COVID-19 on some of affected sectors of India and how this pandemic has distorted the world's thriving economy. Indian tourism has $9.2 \%$ contribution in GDP and the Restriction in mobility can bring $0.45 \%$ down fall in GDP growth rate. In Aviation sector 21 day of lockdown can bring down the revenue to USD1.56 billion which has the contribution of USD72 billion in GDP. It is also highlighted that MSME sectors stare a huge loss in this pandemic, the value to Indian rupee is falling and some losses are also occurred in retail industry which contribute $10 \%$ in GDP and $8 \%$ in employment.

Roy \& Bhusan (2020) [15] studied that how COVID-19 has affected the GST collection and GST scenario in MSME sector. Measures taken to revive MSME sector by GOI has also highlighted and observed that Indian MSMEs will be change in this pandemic, digital practices, work from and innovation will be practiced and Make In India and Digital Practices would be encouraged in future. It is also stated that restriction in exports and imports may help the domestic industry to produce domestically which will further help in improving BOP of the country. It is also concerned that UP which has the largest share of MSME in total MSME in India with $14.20 \%$, second largest West Bengal with 14\% share and followed by Tamilnadu and Maharashtra with $8 \%$ share of MSME need immediate help to survive in future.

Balanagalakshmi \& Kumari (2021)[16] based on the secondary data from various reports, news articles and researches, issues such as procurement of raw materials, migration of workers, shortage in supply of finished goods etc. is highlighted in MSME sector during COVID-19 and relief measures introduced by Government is also studied. It is stated that $20-50 \%$ earnings of MSMEs have impacted during the COVID-19.

In the Union budget 2021-22 [17] GOI has proposed to provide Rs. 15700 crores for Ministry of Micro, Small and Medium Enterprises sector.

Resmi, et al. (2020) [18] studied the condition of MSME business growth before and after covid-19 in Indonesia using primary source of data. It is stated that lockdown caused to decrease in consumption and investment. One sample and paired t-test used to analyze the data and found that there are differences in MSME business growth before and after COVID-19 Pandemic.

\section{Research Methodology}

This paper is based on descriptive analysis using both qualitative and quantitative data from the secondary sources of data from news articles, journals and ministry of MSME. During the pandemic almost every sector of Indian is adversely affected mostly in MSME sector. A Case Study is conducted on many entrepreneurs of MSME in Dhanbad, Bokaro and Ranchi. Researcher has contacted and discussed directors and officials of MSME's of different Districts of Jharkhand to find out the 
problems and challenges they faced during COVID-19 situation and their opinion regarding economic relief provided amid of this pandemic.

\section{Discussion and Analysis}

\section{Problems faced by MSME sectors}

MSME Sector has been facing huge number of problems and challenges due to this world-wide pandemic and the lockdown. Regular manufacturing has halted, flow of goods and services has disrupted, demand has collapsed. Over the $25 \%$ of 6.9 crore India's MSMEs may shut down in this pandemic lockdown ${ }^{19}$.

The current crises require a larger skill shift and need to kick start and pick up the demand first. To get back to their lead MSMEs will need to be focused on many challenges i.e., to undertake outstanding maintenance and services, clean out wasted stocks, shortage of Labours as they have migrated and uncertain situation can also hit exports in which MSME Sector has 48\% contribution in overall exports of India ${ }^{20}$. Disruptive supply chain, collapse in demand, Low liquidity, Disruption in flow of goods and services, Slowdown of service sector, Halted manufacturing are some problems MSME sector has faced during this COVID-19.

\section{Challenges faced by MSME sectors}

Due to this world-wide pandemic and extended lockdown the MSME sector has faced many challenges and will also face in post pandemic situation. The Indian MSME sector need to be ready to confront challenges like; Procurement of raw materials, Debt Repayment, Credit needs, Shortages of Labours, Maintenance and service, clean out wasted stocks and Quality Standardization ${ }^{21}$. No one is willing to take up loans and expand their production as the demand of consumer has declined. Bank were also not taking interest in proving credit. During covid-19 many workers migrated which vacated the required workers in enterprise and production being affected due to lack of skilled workers. After the COVID-19 pandemic it would be challenging for Entrepreneurs to maintain the growth of MSMEs. MSME has larger contribution in country's GDP, employment generation after agriculture and in total exports. After COVID-19 situation for both entrepreneurs and government will have to adopt many strategies to recover losses, revival of units and growth in future. The pandemic has brought new culture and tradition to work. during COVID-19 digital practice, innovation, e-marketing and work from home is become crucial and it will continue in future. Digital transformation of business, training of workforce with digital practice and fluence working with internet will be challenging for MSMEs.

\section{Strategies for revival of MSME sectors}

Aatm Nirbhar Bharat: During this pandemic period Government of India has come up with the package of 20 lakh crore rupees for the 'Self-Reliant India Scheme (Aatm Nirbhar Bharat Abhiyaan)' to recover and revive the Economy, in which MSME 
sectors are also focused [22]. For the improvement in MSME Sector Govt. of India has some strategies such as long-term repo rate operation, 3 lakh crore collateral free loans norms, cheaper interest, extension of the RBI moratorium and wage support, Government e-Marketplace (GeM) for local manufacturing and warehouses for exporters. Six relief measures for MSME sector under the Aatm Nirbhar Bharat Scheme are:

1. Definition of MSME changed - criteria of defining MSMEs changed to break the limit of enterprises to expand.

Table 1 : Definition of MSME

\begin{tabular}{|c|c|c|c|}
\hline \multicolumn{4}{|l|}{ Old MSME Definition } \\
\hline \multicolumn{4}{|c|}{ Criteria: Investment in plants and machinery equipment } \\
\hline Sectors & Micro & Small & Medium \\
\hline Manufacturing & $\begin{array}{l}\text { Investment } \\
<25 \text { lacs }\end{array}$ & $\begin{array}{l}\text { Investment }<5 \\
\text { Cr. }\end{array}$ & $\begin{array}{l}\text { Investment }<10 \\
\text { Cr. }\end{array}$ \\
\hline Service & $\begin{array}{l}\text { Investment } \\
<10 \text { lacs }\end{array}$ & $\begin{array}{l}\text { Investment }<2 \\
\text { Cr. }\end{array}$ & $\begin{array}{l}\text { Investment } \\
\text { Cr. }\end{array}$ \\
\hline \multirow{2}{*}{\multicolumn{4}{|c|}{$\begin{array}{l}\text { New MSME Definition } \\
\text { Composite Criteria: Investment and annual turnover }\end{array}$}} \\
\hline & & & \\
\hline Sectors & Micro & Small & Medium \\
\hline $\begin{array}{l}\text { Manufacturing \& } \\
\text { Service }\end{array}$ & $\begin{array}{l}\text { Investment }<1 \\
\text { Cr. } \\
\text { Turnover }<5 \mathrm{Cr} \text {. }\end{array}$ & $\begin{array}{l}\text { Investment }<10 \mathrm{Cr} \\
\text { Turnover }<50 \mathrm{Cr} \text {. } \\
\text { Tut }\end{array}$ & $\begin{array}{l}\text { Investment }<50 \mathrm{C} \\
\text { r. } \\
\text { Turnover }<250 \mathrm{Cr} \text {. }\end{array}$ \\
\hline
\end{tabular}

Source: Ministry of Micro, Small and Medium Enterprise[23]

2. Credit and Finance Scheme - under the Aatm Nirbhar Bharat Scheme 3.7 lakh crore rupees collateral free loans will be provided to MSME sector which will directly benefit to 45 lakh MSME unit. MSME unit with 100 crores will have relief in loan. Scheme benefits from $31^{\text {st }}$ October 2020 . There will be no need to return principle in first one year.

3. Allocating fund of funds for Equity Participation - there is a provision of 50,000 crores equity infusion through MSME fund of funds to those which has no opportunity or facility to expand the size of enterprise. 
4. Relief in Non-Performing Asset - to support the stressed MSMEs Government of India is providing Rs. 20,000 crore as subordinate debt which will benefit two lakhs MSMEs.

5. Clearing off dues to MSMEs - Government of India has taken a decision to release all dues to MSMEs within 45 days.

6. Disallowing Global Tenders - under this scheme global tender will be disallowed upto Rs. 200 crores to avoid unfair competition from foreign companies and to support Make in India.

Five Task Force: government of India took the decision to set up five task forces during this pandemic to prepare Indian MSMEs for future and to prepare solid strategies to make Indian MSMEs country's main exporter [24]. These task force will work for a month of five main focused MSME which needed to be extended under the leadership of chief officers of MSME. five task forces are below:

1. One of the recognized sectors is Industry 4.0 that includes Artificial intelligence, 3D and Virtual reality. The first task force is aiming to make Industry 4.0 a global.

2. Second task force will focus on Export upgradation and decline in import. Manufacturing sector will be focused to promote industry's export and make a main exporter in world.

3. Third task force will regulate the existing cluster plans to help micro level enterprises with modernized enterprises.

4. Fourth task force will be set to Focus on the way to integrate our technological centres.

5. Fifth task force will work on vivid modernization planning like ZED (Zero Demerit and Zero Effect) \& LEAN (for manufacturing competition).

The Entrepreneurs of MSME has mixed reaction for the new classification of MSME. As the livelihood of many people has been affected in the pandemic, the demand for goods and services in economy has reduced.

After the discussion with many entrepreneurs, it is found that the demand of economy has declined due to low purchasing power parity in the pandemic situation which caused producers not to expand their production nor take interest in getting loan offerings provided by the government under the Aatm Nirbhar Bharat Scheme.

\section{Post pandemic revival strategy}

After the pandemic situation MSME will need to adopt some post pandemic revival strategies to sustain. Some of strategies would be Digital Practice, training of workforce for digital transformation, High Credit Support and Available working 
capital, Sustainable Practice and Innovation. Digital practice, work from home culture and start-ups need to be pushed to rejuvenate MSME sector. Government will have to take extra concern to revive MSME as this sector has crucial role in Indian Economy.

\section{Limitation}

The area of study is limited in Dhanbad, Bokaro and Ranchi District. To save the time and effort only three districts are selected for case study. It is only based on the case study conducted on many entrepreneurs of MSMEs of three districts. This paper is descriptive analysis of problem, challenges and strategies for revival. No any statistical tools and techniques are used. This research can be conducted on a large scale to get more accurate and authentic result.

\section{Future scope of the study}

This paper further will help to assess the problem entrepreneurs faced during pandemic and will be helpful to practice post pandemic revival strategies. This paper will be useful for government to prepare and plan strategies for the revival and survival of MSMEs and also can be benefited in policy making. This work can be a base for further researches. Field back of this study can be explored for future study. This study can be explored by many upcoming researches.

\section{Conclusion}

The MSME sector has faced many problems and challenges due current adverse situation of COVID-19. During this pandemic situation MSME sector has many problems and challenges but survived by opting essential commodity business; like production of reusable masks, hand sanitizers, gloves, PPE kits etc. MSME sector have to generate more employment in future to meet the required working force. During the uncertain situation of COVID-19 Government of India came up with Aatm Nirbhar Bharat scheme to boost market confident and bring back the regular cash flow in Economy. Many Entrepreneurs have mixed opinion regarding the change of the classification of MSME amid COVID-19. As the purchasing power parity of consumers have reduced no any industry is willing to increase their production nor to take up this scheme. Work from home, innovation, digital practices, e-marketing has become an integral part of new culture of industry. Make in India and digital India will need to encourage in post pandemic situation.

\section{Acknowledgement}

We acknowledge our deepest gratitude to previous researchers on this subject whose work immensely benefited us. 


\section{Declaration of Conflict of Interest}

The authors declared no potential conflicts of interest with respect to the research, authorship, and/or publication of this article.

\section{Funding}

The author received no financial support for the research, authorship, and/or publication of this article.

\section{References}

1. TIMES

$\mathrm{OF}$

INDIA,

$23 / 09 / 2020$

https://timesofindia.indiatimes.com/blogs/agyeya/covid-19-affect-on-microsmall-and-medium-enterprises-msmes/ [Accessed on 13/01/2021]

2. TIMES OF INDIA, $23 / 09 / 2020$ https://timesofindia.indiatimes.com/blogs/agyeya/covid-19-affect-on-microsmall-and-medium-enterprises-msmes/ [Accessed on 13/01/2021]

3. Prasanna, P. J. (2017). Growth of MSME Sectors in India. International Research Journal of Management Sociology \& Humanity. 8(12), (178-184).

4. Ahmed, I. (2017). Entrepreneurship Development and Challenges faced by Entrepreneurs in MSME Sector: A Study of J \& K. International Research Journal of Commerce Arts \& Science (CASIRJ), 8(3), 04-12.

5. Kulkarni, D. (2020). Impact of COVID-19 on MSMEs. International Research Journal of Commerce, Arts \& Science (CASIRJ). 11(4), 120-122.

6. Panda, A. K. (2020). MSME IN ODISHA: Opportunity \& Challenges in general \& Post COVID SCENARIO. Journal of Xidian University. 14(6), 1666-1670.

7. Lal, B. S., Sachdeva, P., Simran \& Mittal, T. (2020). Impact of Covid-19 on micro, small and medium enterprises (MSMEs): An overview. International Journal of Multidisciplinary Research and development. 7(11), 05-12.

8. Sipahi, E. (2020). Covid 19 and MSMEs: A Revival Framework. Research Journal in Advanced Humanities, 1(2), 7-21.

9. Affandi, A., Sarwani, A. S., Erlangga, H., Siagian, A. O., Purwanto, A., Effendy, A. A., ... \& Juhaeri, G. (2020). Optimization of MSMEs Empowerment in Facing Competition in the Global Market during the COVID-19 Pandemic Time. Systematic Reviews in Pharmacy, 11(11), 1506-1515.

10. Sahoo, P., \& Ashwani. (2020). COVID-19 and Indian economy: Impact on growth, manufacturing, trade and MSME sector. Global Business Review, 21(5), 1159-1183. 
11.Dubey, P. \& Sahu K. K. (2020). MSMEs in COVID-19 crisis and India's economic relief Package: A critical review. The International Journal of Indian Psychology, 8(4), 1651-1656.

12.Roy, A., Patnaik, B. C. M., \& Satpathy, I. (2020). Impact of Covid-19 crisis on Indian MSME sector: A study on remedial measures. Eurasian Chemical Communications, 2(9), 991-1000.

13.Jha, S. K., \& Kumar, A. (2020). Revitalizing MSME sector in India: Challenges and the road ahead. Journal of Politics \& Governance, 8(5), 4-11.

14. Chaudhary, M., Sodani, P. R., \& Das, S. (2020). Effect of COVID-19 on economy in India: Some reflections for policy and programme. Journal of Health Management, 22(2), 169-180.

15. Roy, A., \& Bhusan, B. (2020). Impact Of Covid-19 On Goods And Services Tax (GST) With Respect To Micro Small And Medium Enterprises (MSME) Sector. PalArch's Journal of Archaeology of Egypt/Egyptology, 179), 47924799 .

16. Balanagalakshmi, B., \& Kumari, S. S. (2021). Covid 19: Impact of Msmeson Indian Economy. Annals of the Romanian Society for Cell Biology, 25(3), 18221827.

17. Government of India Ministry of Finance, 01/02/2020 https://www.indiabudget.gov.in/doc/Budget_Speech.pdf [Accessed on 10/01/2021]

18. Resmi, S., Pahlevi, R. W., \& Sayekti, F. (2020). The growth of creative micro, small, and medium enterprises (MSMES) business in special region of yogyakarta before and after covid-19 pandemic. International Journal of Entrepreneurship, 24(4), 1-8.

19.TIMES OF INDIA,

$23 / 09 / 2020$

https://timesofindia.indiatimes.com/blogs/agyeya/covid-19-affect-on-microsmall-and-medium-enterprises-msmes/ [Accessed on 13/01/2021]

20. FINANCIAL EXPRESS Read to Lead, 08/12/2020 https://www.financialexpress.com/industry/sme/centre-aims-to-increase-msmesector-contribution-to-gdp-up-to-50-gadkari/2145902/ [Accessed on 13/01/2021]

21. Indifi https://www.indifi.com/blog/covid-19-challenges-faced-by-msme/[ Accessed on 13/01/2020]

22. Ministry of Micro, Small \& Medium Enterprises, 20/05/2020 https://msme.gov.in/sites/default/files/AtmanirbharPresentationPart1BusinessincludingMSMEs13-5-2020 0.pdf [Accessed on 12/01/2021]

23. Ministry of Micro, Small \& Medium Enterprises, 01/07/2020 https://msme.gov.in/know-about-msme [Accessed on 12/01/2021] 
24. Business Standard, press trust of India, new Delhi, 24/09/2020 https://www.business-standard.com/article/economy-policy/govt-forms-fivetask-forces-to-make-indian-msmes-future-ready-secy-120092401549_1.html [Accessed on 10/01/2021] 